\title{
LEKSYKA POTOCZNA W PODRECZNIKU DO NAUKI JEZZYKA POLSKIEGO JAKO OBCEGO POLSKI, KROK PO KROKU (POZIOM A1) - WYBRANE ZAGADNIENIA W UJĘCIU STATYSTYCZNYM
}

Słowa kluczowe: słownictwo potoczne, język polski jako obcy, glottodydaktyka, podręczniki do nauki języka polskiego jako obcego, statystyka

Streszczenie. Niniejszy artykuł został poświęcony leksyce potocznej w podręczniku Polski, krok po kroku (poziom A1) w ujęciu statystycznym. Z omawianego podręcznika autor wynotował 103 hasła potoczne, które zostały użyte 541 razy. Na tej podstawie wyliczono średnią częstość wyrazów potocznych oraz wyodrębniono słownictwo kolokwialne bardzo częste, częste, rzadkie i bardzo rzadkie. W artykule przedstawiono także ślepą listę rangową słownictwa potocznego oraz jego podział na części mowy. Przedstawione badania prowadzą do wniosku, że tylko jedna piąta wyrazów potocznych ma szansę utrwalić się na zajęciach lektoratowych z języka polskiego. Pozostałe wyrazy potoczne wprowadzają przede wszystkim wrażenie potoczności i służą urozmaiceniu tekstów w podręczniku, a nie są przedmiotem celowego nauczania.

Podręczniki do nauczania języka polskiego jako obcego - także na poziomie podstawowym A1 - sięgają do ogólnopolskiej odmiany polszczyzny potocznej (Piętkowa 1993, s. 58). Język potoczny ${ }^{1}$ obecny jest zwłaszcza w skryptach napi-

*konrad.szamryk@wp.pl, Instytut Filologii Polskiej, Uniwersytet w Białymstoku, 15-420 Białystok, Plac Uniwersytecki 1.

${ }^{1} \mathrm{~W}$ językoznawstwie polskim funkcjonują dwie koncepcje potoczności. W szerszym ujęciu (antropologicznym) polszczyzna potoczna jest kategorią semantyczno-kulturową, na którą składają się dwa rejestry: neutralny i nacechowany (emocjonalny). W ujęciu węższym polszczyzna potoczna stanowi natomiast kategorię stylistyczno-semantyczną, prymarnie mówioną, mniej staranną, nacechowaną emocjonalnie (Zdunkiewicz-Jedynak 2008, s. 96-97). W niniejszym artykule, mówiąc o polszczyźnie potocznej, odwołuję się do perspektywy węższej. Przyjmuję, głównie za Władysławem Lubasiem, że polszczyzna potoczna jest odmianą języka o charakterze ogólnym, ograniczoną w komunikacji głównie do aktów mowy na poziomie kontaktów indywidualnych i lokalnych, poddaną częściowej kodyfikacji, odznaczającą się bogatą ekspresją i waloryzacją (Lubaś 2003, s. 243-245). Jest ona opozycyjna wobec odmiany ogólnej standardowej o wysokim stopniu kultury- 
sanych w duchu podejścia komunikacyjnego (Szamryk 2016, s. 108-109), które w nauczaniu języków obcych zmieniło nie tylko metodę, ale także sam przedmiot nauczania - stał się nim w większym zakresie język mówiony, a ściślej rzecz biorąc, potoczny (Tambor 2010, s. 312-314).

Współcześnie od polszczyzny potocznej w nauczaniu obcokrajowców nie da się uciec, szczególnie jeśli uznamy, że celem nadrzędnym procesu glottodydaktycznego jest nauczenie cudzoziemców języka mówionego, używanego w codziennej komunikacji, związanego z konkretnymi, ale też najbardziej typowymi sytuacjami życiowymi. Na nauczanie polszczyzny codziennej zwraca się nawet uwagę w Standardach wymagań dla poszczególnych poziomów zaawansowania znajomości języka polskiego, gdzie począwszy od poziomu podstawowego - w odniesieniu do sprawności mówienia i pisania - znajdujemy następujące zalecenie: „zdający powinni umieć posługiwać się zwrotami językowymi charakterystycznymi dla oficjalnej i nieoficjalnej odmiany języka polskiego odpowiednio do sytuacji (...)" (Standardy 2003, s. 12911).

Przyjęcie podejścia komunikacyjnego zaowocowało także nowymi pod względem metodycznym podręcznikami do nauczania języka polskiego jako obcego, takimi jak chociażby seria podręczników Hurra². Metodę tę zastosowały także autorki - obecnie chyba jednej z najpopularniejszych i najczęściej wykorzystywanych przez lektorów - serii podręczników do nauczania języka polskiego jako obcego Polski, krok po kroku, o czym piszą następująco:

Polski, krok po kroku zanurzy Cię w polskim środowisku, gdzie będziesz zmuszony używać polskiego na okrągło, w rozmaitych sytuacjach codziennych. (Kpkl, s. 2)

Książka Polski, krok po kroku jest napisana tylko po polsku, gdyż taka metoda przekazywania materiału przynosi najlepsze efekty. (...) Atutem książki jest bogactwo słów i zwrotów, także tych z języka codziennego. Materiał gramatyczny jest zawsze wprowadzany w kontekście sytuacji komunikacyjnych. (Kpkl, s. 180)

W niniejszym artykule chciałbym przyjrzeć się w perspektywie statystycznej leksyce potocznej w skrypcie do nauczania języka polskiego jako obcego na poziomie A1: Polski, krok po kroku. Poziom A1 $1^{3}$ jest to bowiem podręcznik, który w znacznym stopniu wykorzystuje potoczną odmianę polszczyzny, czemu dała wyraz Iwona Dembowska-Wosik w recenzji rzeczonych materiałów:

Warto zwrócić uwagę na teksty zawarte w podręcznikach serii Polski, krok po kroku. $\mathrm{Z}$ jednej strony wyróżnia je naturalność i humor, z drugiej - szczególnie w pierwszych

zacji oraz opozycyjna wobec odmian nieogólnych, takich jak dialekty, żargony, idiolekty. Zajmuje więc miejsce pośrednie między odmianą ogólną standardową a nieogólną (SPLP, s. V).

${ }^{2}$ M. Małolepsza, A. Szymkiewicz, Hurra!!! Po Polsku 1. Podręcznik studenta, Kraków 2006; A. Burkat, A. Jasińska, Hurra!!! Po polsku 2. Podręcznik studenta, Kraków 2010; A. Burkat i in., Hurra!!! Po polsku 3. Podręcznik studenta, Kraków 2010.

${ }^{3}$ I. Stempek i in., Polski, krok po kroku. Poziom A1, Kraków 2011, dalej jako: Kpk1. 
rozdziałach podręcznika - zawierają one wiele elementów nieznanych jeszcze uczącym się. Utrudnia to znacznie ich rozumienie i stawia nauczyciela wobec konieczności ich tłumaczenia, które (przy konsekwentnym unikaniu języka pośredniego) może okazać się zadaniem karkołomnym, jeśli nie niemożliwym (Dembowska-Wosik 2014, s. 414).

oraz:

Autorom serii nie udało się jednak uniknąć kilku potknięć, które nieco utrudniają pracę z książką. Pierwszym jest wspomniany już wcześniej język tekstów, który - choć naturalny i miły w lekturze - jest jednak często zbyt trudny dla studentów na poziomie $\mathrm{A}^{4}$ (Dembowska-Wosik 2014, s. 414).

Uwagi Iwony Dembowskiej-Wosik wymagają pewnego uzupełnienia. Zarówno ,naturalny i miły w lekturze [język - przyp. K.Sz.] (...) jednak często zbyt trudny dla studentów na poziomie A”, jak i ,elementy nieznane jeszcze uczącym się" to w znacznej mierze elementy polszczyzny potocznej. Trudność, ale jednocześnie atrakcyjność omawianej serii podręczników, wynika z wprowadzenia w tekstach i ćwiczeniach stylizacji na język mówiony w odmianie nieoficjalnej.

Różnice między polszczyzną oficjalną (w tym wspólnoodmianową) a potoczną uwidaczniają się przede wszystkim na poziomie składni i leksyki (Wilkoń 2000, s. 44-45). Tym bardziej więc uzasadnia to konieczność przeprowadzenia badań nad słownictwem potocznym w ujęciu ilościowym i jakościowym. W kolejnych szkicach chciałbym prześledzić sposób wykorzystania omawianej leksyki oraz odpowiedzieć na pytanie, jaką funkcję pełnią te wyrazy w podręczniku.

Warto jednak dodać, że w tekstach literackich - oraz między innymi w podręcznikach do nauczania obcokrajowców języka polskiego - w celu wprowadzenia elementu oralnego wyzyskuje się - oprócz składni i leksyki - również ortografię i interpunkcję (Święcicka 1999, s. 235, Skudrzykowa 1994, s. 51-73), a w mniejszym zakresie także fleksję, słowotwórstwo czy frazeologię. O ile jednak środki graficzne wykorzystane w tekście w celu stworzenia wrażenia mówioności są właściwie automatycznie dekodowane przez osobę uczącą się języka ${ }^{5}$ o tyle wprowadzenie słownictwa kolokwialnego rodzić może wątpliwości i pytania związane z przypisaniem leksemów do odpowiedniego poziomu rejestru językowego (Szamryk 2016, s. 115-116). Tego typu wątpliwości uwidaczniają się szczególnie w sytuacji, gdy na zajęciach pojawiają się synonimiczne jednostki wyrazowe, które różnicuje nacechowanie ekspresywne, np.: ojciec - tata, matka - mama, język polski-polski, ponieważ-bo, dziękuje - dzięki, pieniadze - kasa ${ }^{6}$.

${ }^{4}$ Tamże, s. 415 .

${ }^{5} \mathrm{O}$ problemie dekodowania i interpretacji elementów graficznych w tworzeniu wrażenia oralności w podręczniku piszę w artykule Kreacja mowy potocznej w podręczniku do nauki języka polskiego jako obcego „Polski, krok po kroku” (poziom A1) - tekst w druku. Zob. również A. Skudrzykowa 1994, s. 51-69.

${ }^{6}$ Wszystkie pary jednostek wyrazowych wynotowano z podręczników Kpk1. 
W analizowanym podręczniku, zarówno w scenkach dialogowych, jak i w ćwiczeniach, odnajdujemy 103 leksemy potoczne ${ }^{7}$, które przedstawia zamieszczony na końcu artykułu aneks w postaci tabeli wyrazów potocznych w układzie frekwencyjnym. Wynotowane leksemy $(\mathrm{W}=103)$ zostały łącznie użyte w całym podręczniku 541 razy (liczba potocznych wyrazów tekstowych - N).

Przystępując do badania słownictwa potocznego w podręczniku Kpkl, warto ustalić, jaki procent wyrazy kolokwialne stanowią na tle całości tekstu. Na potrzeby niniejszego artykułu można przyjąć, że Kpk1 składa się 26 jednostek lekcyjnych, które zajmują 172 strony. Pojemność tekstowa skryptu wynosi w przybliżeniu 43000 wyrazów tekstowych ${ }^{8}$. Oznacza to, że tekst podręcznika w 1,26\% składa się z leksyki potocznej, a więc w przybliżeniu co 79 wyraz w książce Kpkl stanowi słowo należące do nieoficjalnego zasobu leksykalnego polszczyzny9. Nie można więc uznać, że słownictwo nieoficjalne stanowi podstawowy zrąb leksykalny książki.

$\mathrm{Z}$ drugiej jednak strony warto pamiętać, że mamy do czynienia z podręcznikiem przeznaczonym dla obcokrajowców na poziomie A1, a więc zawierającym słownictwo najbardziej podstawowe i w założeniu charakteryzujące się niewielkim stopniem zróżnicowania. Jeśli dla porównania przypomnimy, że lista słów przygotowana przez Waldemara Martyniuka dla elementarnego poziomu zaawansowania w języku polskim jako obcym liczy sobie 918 wyrazów (Martyniuk 2004, s. 55-56), a dla poziomu I w SPJP około 1800 słów, to zbiór 103 haseł potocznych wydaje się wcale niemały. Nie można więc przyjąć, że analizowana warstwa słownictwa potocznego, składająca się z nieco ponad stu leksemów, jest nieistotna i nie odgrywa większej roli na lektoracie językowym, prowadzonym zwłaszcza przy wykorzystaniu podręcznika Kpkl.

Aby lepiej uchwycić strukturę wyekscerpowanego słownictwa potocznego, warto obliczyć kolejne parametry statystyczne. Jednym z czynników przynoszącym pewne wyobrażenie o frekwencji i częstości użycia wyrazów jest ślepa lista rangowa (Sambor 1978, s. 60-61). Znajdują się w niej tylko podstawowe dane

${ }^{7}$ Podana liczba obejmuje tradycyjne leksemy oraz wyrażenia wieloskładnikowe, spełniające kryterium niepodzielności semantycznej. Do obliczeń nie włączam semileksemów oraz związków frazeologicznych (zob. SPLP, s. IX). O kryteriach i problemach z wyodrębnianiem słownictwa potocznego w podręcznikach do nauczania języka polskiego zob. K. Szamryk 2016, s. $107-119$.

${ }^{8}$ Podana wartość ma charakter przybliżony i nie wynika ze szczegółowych obliczeń. Została określona za pomocą programu Microsoft Word. W obliczeniach pominąłem wstęp, spis treści, zakończenie oraz informacje o autorach i samym podręczniku.

${ }^{9}$ Dla porównania, słownictwo wojskowe w Trylogii H. Sienkiewicza uznano za podstawowy zrąb leksyki powieści, gdyż obejmuje 8\% (co 12 wyraz) zasobu wyrazowego cyklu (Mariak 2011, s. 39). Z kolei w Panu Tadeuszu A. Mickiewicza wyrazy obce stanowią 5,47\% (co 18-19 wyraz w tekście) (Zarębina 1977, s. 71). Generalnie jednak wyrazy obce w tekstach artystycznych z XIX wynoszą od 4-6\%, co M. Zarębina interpretuje jako wyrazy z niską lub bardzo niską frekwencja (1977, s. 105-106), a w prasie od 7 do 15\% (Pisarek 1972, s. 49). 
liczbowe, do których należą: częstość wyrazów (f), ranga (r) przyporządkowana każdej z tych częstości oraz liczba wyrazów (m). Zawarte w ślepej liście rangowej dane liczbowe pokazują, ile wyrazów powtarza się często, a ile rzadko lub wyjątkowo, gdyż mają niską frekwencję. Podana poniżej tabela 1 stanowi ślepą listę leksemów potocznych według częstości użycia w podręczniku Kpkl:

Tabela 1. Rozkład liczby wyrazów potocznych według częstości użycia w Kpkl (ślepa lista rangowa)

\begin{tabular}{|c|c|c|c|c|c|c|c|c|}
\hline $\begin{array}{c}\text { Ranga } \\
(\mathrm{r})\end{array}$ & $\begin{array}{c}\text { Czę- } \\
\text { stość } \\
(\mathrm{f})\end{array}$ & $\begin{array}{c}\text { Liczba } \\
\text { wyra- } \\
\text { zów } \\
(\mathrm{m})\end{array}$ & $\begin{array}{c}\text { Ranga } \\
(\mathrm{r})\end{array}$ & $\begin{array}{c}\text { Czę- } \\
\text { stość } \\
(\mathrm{f})\end{array}$ & $\begin{array}{c}\text { Liczba } \\
\text { wyra- } \\
\text { zów } \\
(\mathrm{m})\end{array}$ & $\begin{array}{c}\text { Ranga } \\
(\mathrm{r})\end{array}$ & $\begin{array}{c}\text { Czę- } \\
\text { stość } \\
(\mathrm{f})\end{array}$ & $\begin{array}{c}\text { Liczba } \\
\text { wyra- } \\
\text { zów } \\
(\mathrm{m})\end{array}$ \\
\hline 1. & 69 & 1 & 7. & 16 & 3 & 13. & 6 & 3 \\
\hline 2. & 54 & 1 & 8. & 14 & 2 & 14. & 5 & 3 \\
\hline 3. & 37 & 1 & 9. & 13 & 1 & 15. & 4 & 6 \\
\hline 4. & 31 & 1 & 10. & 9 & 1 & 16. & 3 & 9 \\
\hline 5. & 26 & 1 & 11. & 8 & 2 & 17. & 2 & 22 \\
\hline 6. & 19 & 1 & 12. & 7 & 3 & 18. & 1 & 42 \\
\hline
\end{tabular}

Źródło: opracowanie własne

W zawierającej 18 pozycji ślepej liście rangowej, pojedyncze wyrazy o najwyższej częstości stanowią blisko jej połowę. Można więc wyciągnąć wiosek, że ważną część leksyki potocznej w Kpkl stanowią pojedyncze kolokwializmy, konsekwentnie i często powtarzane w tekście. Począwszy od pozycji 15, dla wyrazów o częstości w zakresie 4-1, obserwuje się zdecydowane zwiększenie ilości wyrazów przy jednoczesnym spadku częstości ich powtarzania. Drugą więc, również znaczącą grupę leksemów potocznych w Kpkl, stanowią te klasy wyrazów, które nie są powtarzane w tekście, pojawiają się incydentalnie, przez co praktycznie nie mają szans, aby zapaść w pamięć osobom uczącym się języka polskiego z książki Kpkl. Analizowany materiał charakteryzuje się więc znaczną rozpiętością frekwencji, choć do powyższych wniosków, ze względu na relatywnie mały zbiór leksemów, należy podchodzić z pewną ostrożnością.

Z kolei stosunek wyrazów tekstowych $(\mathrm{N}=541)$ do liczby wyrazów hasłowych $(\mathrm{W}=103)$ pozwala wyliczyć wskaźnik średniej częstości wyrazów potocznych w tekście (F), który dla potocyzmów w podręczniku Kpkl wynosi 5,25. Obliczona wartość $\mathrm{F}$ odnosi się jedynie do tej partii tekstu, którą pokrywają potocyzmy. W lingwistyce statystycznej przyjmuje się, że mała średnia częstość (wartość jednocyfrowa) świadczy o przewadze w tekście słownictwa rzadkiego, a tym samym o bogactwie zasobu leksykalnego. Frekwencja jednostek potocznych o wartości $5,25^{10}$ wskazuje na to, że leksyka potoczna w podręcznikach jest zróżnicowana oraz

${ }^{10}$ Wskaźnik częstości słownictwa wojskowego w Trylogii H. Sienkiewicza wynosi 21 (Mariak 2011, s. 50), a wyrazów obcych w Panu Tadeuszu A. Mickiewicza 2,85 (Zarębina 1977, s. 71), przy 
dominuje słownictwo frekwencyjnie rzadkie, co nie sprzyja raczej utrwaleniu i zapamiętaniu potocznych jednostek. Niska frekwencja leksyki potocznej w płaszczyźnie treści nadaje więc przede wszystkim pewien koloryt, służy raczej wprowadzeniu wrażenia potoczności, a w płaszczyźnie języka urozmaiceniu i uatrakcyjnieniu tekstu, a nie wzmacnianiu znajomości słownictwa kolokwialnego.

Na podstawie obliczonego wskaźnika częstości wyrazów potocznych można wyodrębnić leksemy częste (o częstości większej niż F) oraz rzadkie (o częstości niższej niż wartość F). W celu jednak dokładniejszego przeanalizowania omawianego zbioru, proponuję wyodrębnić 4 klasy wyrazów ${ }^{11}$. Klasy częstości wyrazów potocznych w Kpkl przedstawia tabela 2.

Tabela 2. Klasy częstości leksemów potocznych w Kpk1

\begin{tabular}{|l|c|c|c|c|}
\hline \multirow{2}{*}{ Częstość } & \multicolumn{2}{|c|}{ Wyrazy hasłowe } & \multicolumn{2}{c|}{ Użycia } \\
\cline { 2 - 5 } & Liczba & $\%$ & Liczba & $\%$ \\
\hline Powyżej 10 & 12 & 11,65 & 325 & 60,07 \\
\hline $10-6$ & 9 & 8,74 & 64 & 11,83 \\
\hline $5-2$ & 40 & 38,83 & 110 & 20,33 \\
\hline 1 & 42 & 40,78 & 42 & 7,77 \\
\hline
\end{tabular}

Źródło: opracowanie własne.

Wprowadzony przeze mnie podział na 4 klasy częstości wyrazów wynika z uwzględnienia zarówno kryteriów statystycznych, jak i glottodydaktycznych. Oprócz słownictwa częstego (w przedziale 10-6) wyróżniam klasę potocyzmów bardzo częstych, a więc takich, które powtarzają się w podręczniku więcej niż 10 razy, w związku z czym istnieje duże prawdopodobieństwo, że wyrazy te zostaną zapamiętane przez ucznia ${ }^{12}$. Z kolei słownictwo rzadkie tworzą leksemy o częstość 5-2, a bardzo rzadkie to hapax legemena (częstość równa 1).

Do słownictwa potocznego bardzo częstego i częstego w Kpkl zalicza się 21 jednostek leksykalnych. Wyrazy bardzo częste to: bo, cześć, no, mama, tata, komórka, polski 'język polski', (wszystko) w porządku, dziewczyna 'sympatia, narzeczona', impreza, wiesz, Anglia, a częste: jasne 'oczywiście', fajny, kilo, babcia, o tak 'dobrze, zgoda', w końcu, chłopak 'narzeczony, partner', super, wujek.

Wyrazy hasłowe potoczne częste i bardzo częste w Kpkl stanowią nieco ponad $20 \%$ wszystkich form hasłowych jednostek potocznych, które użyte zostały

czym w innych tekstach artystycznych z XIX wieku częstość słownictwa obcego oscyluje od 2 do 4 (Zarębina 1977, s. 103-104).

${ }^{11}$ Badacze w swoich opracowaniach dzielą materiał na różną liczbę grup częstości wyrazów. T. Smółkowa wprowadza ich 8 (1974: 83), L. Mariak 7 (2011: 51), M. Zarębina 4 (1977: 71).

${ }^{12}$ A. Seretny, Czytanie ekstensywne, czyli sposób na efektywne rozwijanie kompetencji leksykalnej uczacych się, w: Sztuka to rzemiosło. Nauczyć Polski i polskiego, red. A. Achtelik, J. Tambor, t. 3, Katowice 2013, s. 212. 
w podręczniku 389 razy, co daje 71,9\% wszystkich użytych wyrazów potocznych. Przywołane jednostki o frekwencji wyższej niż średnia, ze względu na niewielkie urozmaicenie, ale częste występowanie w tekście, uznać należy za odgrywające znaczą rolę w tworzeniu podstawowego zrębu słownictwa ogólnego w nauczaniu obcokrajowców języka polskiego jako obcego na poziomie A1.

$\mathrm{Z}$ kolei słownictwo rzadkie oraz bardzo rzadkie stanowi niecałe $80 \%$ wszystkich potocznych haseł, przy czym blisko połowa wyrazów o częstości niższej niż $\mathrm{F}=5,25$ pojawia się w podręczniku Kpkl tylko raz, co po raz kolejny potwierdza tezę o podrzędnej funkcji przeważającej części tego słownictwa w podręczniku na poziomie A1, a tym samym również w procesie dydaktycznym. Na lektoracie prowadzonym przy wykorzystaniu podręcznika $K p k 1$ ma szansę utrwalić się przede wszystkim słownictwo bardzo częste. Pod względem liczby haseł jest go stosunkowo niewiele (11,65\% form hasłowych), ale jego użycia stanowią blisko $60 \%$ użyć całej leksyki potocznej w skrypcie. W Kpkl słownictwo potoczne bardzo częste - na które składa się 12 leksemów - charakteryzuje się znacznym stopniem powtarzalności. Natomiast ponad $80 \%$ wyrazów hasłowych ma w zasadzie niewielkie szanse na to, aby zapaść uczniom w pamięć, gdyż składają się na nie wyrazy rzadkie (o częstości między 5-2) oraz bardzo rzadkie (o częstości równej 1).

Statystyczne ujęcie struktury części mowy leksyki potocznej (tabela 3) pozwala zauważyć, że w Kpkl najczęstszą kategorię haseł potocznych stanowią rzeczowniki (34\% wyrazów hasłowych), a następnie ex aequo uplasowały się przymiotniki, wykrzykniki i przysłówki (14,56\%). Czasowniki uplasowały się tuż po nich, choć ich procentowy udział jest niewiele mniejszy niż wyliczonych części mowy, gdyż wynosi $12,62 \%$.

Tabela 3. Struktura części mowy leksyki potocznej w podręczniku Kpk1

\begin{tabular}{|c|c|c|c|c|c|}
\hline \multirow{2}{*}{} & \multirow{2}{*}{ Części mowy } & \multicolumn{2}{|c|}{ Wyrazy hasłowe } & \multicolumn{2}{c|}{ Użycia } \\
\cline { 3 - 6 } & & Liczba & $\%$ & Liczba & $\%$ \\
\hline 0. & partykuła & 8 & 7,76 & 69 & 12,76 \\
\hline 1. & rzeczownik & 35 & 34 & 207 & 38,26 \\
\hline 2. & przymiotnik & 15 & 14,56 & 39 & 7,2 \\
\hline 3. & liczebnik & 0 & 0 & 0 & 0 \\
\hline 4. & zaimek & 1 & 0,97 & 1 & 0,19 \\
\hline 5. & czasownik & 13 & 12,62 & 19 & 3,51 \\
\hline 6. & przyimek & 0 & 0 & 0 & 0 \\
\hline 7. & wykrzyknik & 15 & 14,56 & 89 & 16,45 \\
\hline 8. & przysłówek & 15 & 14,56 & 48 & 8,87 \\
\hline 9. & spójnik & 1 & 0,97 & 69 & 12,76 \\
\hline
\end{tabular}

Źródło: opracowanie własne 
Jeśli jednak przyjrzymy się strukturze części mowy potocyzmów pod kątem liczby użycia wyrazów tekstowych, to po raz kolejny okaże się, że w Kpkl wykorzystywane są rzeczowniki $(38,26 \%)$, ale w następnej kolejności plasują się wykrzykniki (16,45\%), partykuły i spójniki (12,76\%), przysłówki $(8,87 \%)$ i przymiotniki (7,2\%). Czasowniki pojawiają się dopiero na 7. miejscu (3,51\%), co zdaje się przemawiać za marginalną rolą tej części mowy w zakresie wykorzystania słownictwa potocznego $\mathrm{w}$ analizowanym podręczniku. Zredukowana funkcja czasowników jest szczególnie widoczna, gdy materiał wynotowany z Kpkl zestawimy z innymi opracowaniami tekstów w ujęciu statystycznym. Na przykład w opracowaniu poświęconemu analizie słownictwa polszczyzny mówionej czasowniki stanowiły znaczną część analizowanego słownictwa, gdyż uplasowały się na drugim miejscu, tuż po rzeczownikach (Zarębina 1985, s. 65). Podobnie - drugą pozycję - zajęły czasowniki w polu leksyki wojskowej w Trylogii H. Sienkiewicza (Mariak 2011, s. 75) oraz w Lalce B. Prusa (Smółkowa 1974, s. 75). Wydaje się, że wysoka pozycja tej części mowy - zazwyczaj tuż po rzeczownikach - jest wspólna większości tekstów i nie zależy od gatunku, objętości czy czasu powstania utworu (Mariak 2011, s. 75).

Ponadto zwraca uwagę nienaturalnie wysoka pozycja wykrzykników - zarówno pod względem procentowego udziału w potocznym zasobie wyrazów hasłowych, jak również ich częstego użycia. W polszczyźnie mówionej wykrzykniki nie stanowią częstej kategorii - w tekstach badanych przez Marię Zarębinę pod względem udziału w całości słownika wykrzykniki zajęły 7 pozycję, a jako wyrazy tekstowe - ostatnią $(1985 \text {, s. } 65)^{13}$. Powyższe badania zdają się więc potwierdzać spostrzeżenia nie tylko o nadreprezentacji wypowiedzeń wykrzyknikowych w $K p k 1^{14}$, ale również wykrzykników jako części mowy. Prezentowane wnioski uległyby wzmocnieniu, gdyby analizowaną grupę wyrazów powiększyć o kategorię semileksemów, czyli wyrazów ułomnych, mających znaczenie bardzo ogólne i charakteryzujących się defektami fleksyjnymi (SPLP, s. IX), a które zostały pominięte $\mathrm{w}$ analizowanym przeze materiale leksykalnym. Ponieważ semileksemy, np.: a (8), aaa (4), ach (5), aha (18), auuu (1), bryy (1), cha, chal cha, cha, cha (8), eeeleeee (6), fuj (1), he, he (6), hi, hi (8), hm/hmm/hmmm/hm, hm (10), ho, ho, ho (6), o (21), och (2), oj (3), ojej (3), oooo (1), uff (3), yyy (8), w podziale na części mowy należy klasyfikować jako wykrzykniki, umacnia się teza o silnej pozycji tej kasy wyrazów w ogólnym udziale słownictwa potocznego w skrypcie.

Można przypuszczać, że wysoka pozycja wykrzykników wynika ze struktury zamieszczonych w Kpkl tekstów, na które w przeważającej części składają się

${ }^{13} \mathrm{~W}$ opracowaniu poświęconemu leksyce wojskowej w Trylogii H. Sienkiewicza L. Mariak w ogóle nie wyodrębnia wykrzykników, traktując je zbiorczo jako „inne” części mowy (2011, s. 79), co również przemawia za ich podrzędną rolą $\mathrm{w}$ analizowanym przez badaczkę materiale.

${ }^{14}$ Zob. Szamryk K., Kreacja mowy potocznej w podręczniku do nauki języka polskiego jako obcego „Polski, krok po kroku” (poziom A1) - tekst w druku. 
krótkie dialogi. Omawiane teksty zawierają przede wszystkim pojedyncze zdania lub równoważniki zdań i właściwie pozbawione są dłuższych, kilkuzdaniowych wypowiedzeń. Niemal każda scenka zaczyna się nawiązaniem kontaktu, np.: cześćc, halo, hej, a w części finalnej wyrażeniem zgody - rzadziej dezaprobaty - np.: jasne, o tak, OK, ach tak, dobra, i pożegnaniem, np.: na razie, do jutra, $p a$. W wielu dialogach - zwłaszcza w pierwszych lekcjach podręcznika - omawiane elementy stanowią zasadniczy trzon poszczególnych scenek. Co więcej, w większości z nich interlokutorami są młodzi ludzie - osoby uczące się języka polskiego - to taki sposób budowania tekstów sprzyja występowaniu wykrzykników o kwalifikacji potocznej.

Warto również dodać, że wysoka pozycja spójników jako części mowy wynika właściwie z użycia jednego wyrazu - spójnika przyczynowego bo. Spośród wszystkich wyrazów potocznych jest on najczęściej wykorzystywany w Kpk1, co zwiększa znaczenie całej klasy spójników - w zasadzie ze względu na pełnioną funkcję składniową - jako części mowy. Badacze jednak zwracają uwagę, że spójnik bo jest w ogóle jednym z najpowszechniejszych spójników w polszczyźnie mówionej (Zarębina 1985, s. 103), a ponadto staje się coraz bardziej ekspansywny również w wypowiedziach mówionych o charakterze oficjalnych, przez co nawet w radiu i telewizji zaczyna pełnić funkcję neutralnego stylistycznie wskaźnika zespolenia (Podracki 2014, s. 188).

Niniejszy artykuł stanowi jedynie wprowadzenie do badań nad słownictwem potocznym w podręczniku do nauczania języka polskiego jako obcego Polski, krok po kroku na poziomie A1. Prezentowane wnioski pozwalają jednak zauważyć, że słownictwo potoczne jest obecne w podręczniku Kpkl, a pod względem statystycznym dzieli się na dwie klasy wyrazów - niewielką grupę kolokwializmów często powtarzanych oraz znaczą grupę wyrazów rzadko powtarzanych. Wyrazy kolokwialne służą przede wszystkim wprowadzeniu wrażenia oralności, dzięki czemu stanowią urozmaicenie lekcji prowadzonych z wykorzystaniem podręcznika Kpk1. Tylko około jednej piątej analizowanych leksemów ma szansę, aby utrwalić się podczas prowadzonych zajęć. Nadmiar wykrzykników oraz zmarginalizowana rola czasowników sprawiają ponadto, że pod względem struktury części mowy wyekscerpowany materiał nie oddaje ani specyfiki tekstów mówionych, ani artystycznych, co wynika zapewne z tego, że przygotowane scenki i ćwiczenia powstały głównie z myślą o wykorzystaniu w procesie glottodydaktycznym.

\section{BIBLIOGRAFIA}

Dembowska-Wosik I., 2014, Recenzja serii materiałów do nauczania jpjo „Polski, krok po kroku”, w: Glottodydaktyka - media - komunikacja. Negocjowanie znaczeń, seria „Acta Universitatis Lodziensis. Kształcenie Polonistyczne Cudzoziemców”, t. 21, s. 413-416. 
Grzenia J., 2006, Komunikacja językowa w Internecie, Warszawa.

Kpk1 - Stempek I., Stelmach A., Dawidek S., Szymkiewicz A. i in., 2011, Polski, krok po kroku. Poziom A1, Kraków.

Lubaś W., 2003, Polskie gadanie. Podstawowe cechy i funkcje potocznej odmiany polszczyzny, Opole.

Mariak L., 2011, Leksyka z zakresu wojskowości w ,, Trylogii” Henryka Sienkiewicza, cz. 1. Analiza $i$ interpretacja, Szczecin.

Martyniuk W., 2004, A1 - elementarny poziom zaawansowania w języku polskim jako obcym, Kraków.

Piętkowa R., 1993, Normatywność w podręcznikach języka polskiego dla cudzoziemców, w: A. Wilkoń, J. Warchala (red.), Z problemów wspótczesnego języka polskiego, Katowice, s. $56-66$.

Pisarek W., 1972, Frekwencja wyrazów w prasie. Wiadomości - komentarze - reportaże, Kraków.

Podracki J., 2014, Potoczne elementy językowe w polszczyźnie radia i telewizji, w: M. Kita, I. Loewe (red.), Język w mediach, Katowice, s. 180-188.

Sambor J., 1978, Językoznawstwo statystyczne dla pracowników informacji naukowej, Warszawa.

Seretny A., Czytanie ekstensywne, czyli sposób na efektywne rozwijanie kompetencji leksykalnej uczacych się, w: Sztuka to rzemiosto. Nauczyć Polski i polskiego, red. A. Achtelik, J. Tambor, t. 3, Katowice 2013, s. 208-220.

Skorupka S., 1973, O metodach badań języka autorów, „Przegląd Humanistyczny”, t. 17, z. 5, s. $33-45$.

Skudrzykowa A., 1994, Język (za)pisany, Katowice.

Smółkowa T., 1974, Stownictwo i fleksja „Lalki” Bolesława Prusa. Badania statystyczne, Wrocław-Warszawa-Kraków-Gdańsk.

SPJP - Stownik poziomowy języka polskiego, 2010, red. P. Wróblewski, Białystok.

SPLP - Stownik polskich leksemów potocznych, 2001-2014, red. W. Lubaś, Warszawa, t. 1-7.

Standardy, 2003, Standardy wymagań dla poszczególnych poziomów zaawansowania znajomości języka polskiego, Rozporządzenie Ministra Edukacji Narodowej i Sportu z dnia 15.10.2003 r. w sprawie egzaminów z języka polskiego jako obcego, Dz.U. z dnia 15.10.2003, Nr 191, poz. 1871, s. $12909-12929$.

Szamryk K., 2016, Problemy zwiazane z leksyka potoczna (na przykładzie materiału z podręczników do nauki języka polskiego jako obcego na poziomie A1), w: E. Awramiuk, M. Karolczuk (red.), Z problematyki ksztatcenia językowego, Białystok, t. VI, s. 107-119.

Święcicka M., 1999, Kreacja dialogu potocznego we wspótczesnej polskiej prozie dla młodzieży, Bydgoszcz.

Tambor J., 2010, Granice potoczności w nauczaniu języka polskiego jako obcego przemiany leksykalne, fonetyczne, fleksyjne i stowotwórcze we wspótczesnej polszczyźnie, w: R. Nycz i in. (red.), Polonistyka bez granic t. 2, Glottodydaktyka polonistyczna, Kraków, s. 311-320.

Wilkoń A., 2000, Typologia odmian językowych wspótczesnej polszczyzny, Katowice.

Zarębina M., 1977, Wyrazy obce w „,Panu Tadeuszu”, Wrocław-Warszawa-Kraków-Gdańsk.

Zarębina M., 1985, Próba statystycznej analizy słownictwa polszczyzny mówionej (synteza danych liczbowych), Wrocław-Warszawa-Kraków-Gdańsk.

Zdunkiewicz-Jedynak D., 2008, Wyktady ze stylistyki, Warszawa. 


\section{ANEKS}

Tabela leksemów potocznych w układzie rangowym

\begin{tabular}{|c|c|c|c|c|}
\hline $\begin{array}{l}\text { Ran- } \\
\text { ga }\end{array}$ & Jednostka leksykalna & Znaczenie & $\begin{array}{l}\text { Czę- } \\
\text { stość }\end{array}$ & $\begin{array}{l}\text { Część } \\
\text { mo- } \\
\text { wy }^{\mathrm{a}}\end{array}$ \\
\hline 1. & bo & Ponieważ & 69 & 9 \\
\hline 2. & cześć & witaj, witajcie & 54 & 7 \\
\hline 3. & no & $\begin{array}{l}\text { 1. pauza wypełnieniowa } \\
\text { 2. sygnał zmierzania do konkluzji }\end{array}$ & $\begin{array}{c}37 \\
35 \\
2\end{array}$ & 0 \\
\hline 4. & mama & matka & 31 & 1 \\
\hline 5. & tata & ojciec & 26 & 1 \\
\hline 6. & komórka & telefon komórkowy & 19 & 1 \\
\hline 7. & polski & język polski & 16 & $1^{\mathrm{b}}$ \\
\hline 8. & (wszystko) w porządku & dobrze & 16 & 8 \\
\hline 9. & dziewczyna & $\begin{array}{l}\text { 1. zwrot do młodej kobiety } \\
\text { 2. sympatia, narzeczona, kochanka }\end{array}$ & $\begin{array}{c}16 \\
6 \\
10\end{array}$ & 1 \\
\hline 10. & impreza & spotkanie towarzyskie, zabawa & 14 & 1 \\
\hline 11. & wiesz & $\begin{array}{c}\text { zwrot wtrącony, mający podtrzymać } \\
\text { zainteresowanie słuchacza }\end{array}$ & 14 & 0 \\
\hline 12. & Anglia & Wielka Brytania & 13 & 1 \\
\hline 13. & jasne & oczywiście & 9 & 7 \\
\hline 14. & fajny & $\begin{array}{l}\text { 1. świetny, wspaniały, znakomity } \\
\text { 2. miły, sympatyczny, przyjemny } \\
\text { 3. o stanie technicznym: dobry, porządny } \\
\text { 4. niezły } \\
\text { 5. ciekawy }\end{array}$ & $\begin{array}{l}8 \\
4 \\
1 \\
1 \\
1 \\
1\end{array}$ & 2 \\
\hline 15. & kilo & kilogram & 8 & 1 \\
\hline 16. & babcia & babka & 7 & 1 \\
\hline 17. & o tak & dobrze, zgoda & 7 & 7 \\
\hline 18. & w końcu & nareszcie & 7 & 0 \\
\hline 19. & chłopak & narzeczony, partner & 6 & 1 \\
\hline 20. & super & wspaniale & 6 & 8 \\
\hline 21. & wujek & brat ojca lub matki & 6 & 1 \\
\hline
\end{tabular}




\begin{tabular}{|c|c|c|c|c|}
\hline 22. & firma & marka przedsiębiorstwa & 5 & 1 \\
\hline 23. & okropny & $\begin{array}{l}\text { pozbawiony cech dodatnich, brzydki, } \\
\text { szpetny }\end{array}$ & 5 & 2 \\
\hline 24. & strasznie & bardzo, niezmiernie & 5 & 8 \\
\hline 25. & biała & kawa naturalna z mlekiem & 4 & $2^{c}$ \\
\hline 26. & cola & napój gazowany z kofeiną & 4 & 1 \\
\hline 27. & halo & $\begin{array}{l}\text { 1. wykrzyknik wzywający do zwrócenia } \\
\text { uwagi na dalsze słowa } \\
\text { 2. poufała forma powitania }\end{array}$ & $\begin{array}{l}4 \\
2\end{array}$ & 7 \\
\hline 28. & fantastyczny & bardzo dobry, wyśmienity, niezwykły & 4 & 2 \\
\hline 29. & niezły & dość atrakcyjny, akceptowany & 4 & 2 \\
\hline 30. & prawda & wyraz używany na końcu zdania & 4 & 0 \\
\hline 31. & dzięki & dziękuję & 3 & 1 \\
\hline 32. & normalnie & zwykle, na co dzień & 3 & 8 \\
\hline 33. & od ręki & natychmiast, na poczekaniu & 3 & 8 \\
\hline 34. & $\mathrm{OK}$ & dobrze & 3 & 7 \\
\hline 35. & randka & $\begin{array}{l}\text { umówione spotkanie dwóch osób czują- } \\
\text { cych do siebie sympatię }\end{array}$ & 3 & 1 \\
\hline 36. & serio & poważnie, naprawdę & 3 & 8 \\
\hline 37. & słuchaj/słuchajcie & $\begin{array}{c}\text { zwrot do rozmówcy mający skupić jego } \\
\text { uwagę }\end{array}$ & 3 & 0 \\
\hline 38. & szef & dyrektor, kierownik & 3 & 1 \\
\hline 39. & zero & brak czegoś, nic & 3 & $1^{\mathrm{d}}$ \\
\hline 40. & ach tak & a więc to tak, no proszę & 2 & 7 \\
\hline 41. & biec & podążać szybko, przybywać pośpiesznie & 2 & 5 \\
\hline 42. & bosko & bardzo dobrze, wspaniale, znakomicie & 2 & 8 \\
\hline 43. & do jutra & pożegnanie do następnego dnia & 2 & 7 \\
\hline 44. & drink & napój z alkoholem & 2 & 1 \\
\hline 45. & faktycznie & rzeczywiście & 2 & 0 \\
\hline 46. & fantastycznie & znakomicie, wspaniale & 2 & 8 \\
\hline 47. & gratis & bezpłatnie, za darmo & 2 & 8 \\
\hline 48. & hiszpański & język hiszpański & 2 & 1 \\
\hline 49. & iść & $\begin{array}{l}\text { 1. coś ulega przemianie, zmienia się } \\
\text { 2. dzieje się, toczy, przebiega }\end{array}$ & $\begin{array}{l}2 \\
1 \\
1\end{array}$ & 5 \\
\hline 50. & kiepski & lichy, marny, nędzny, niewyszukany & 2 & 2 \\
\hline
\end{tabular}




\begin{tabular}{|c|c|c|c|c|}
\hline 51. & kochana & $\begin{array}{l}\text { poufały, przymilny zwrot apelatywny do } \\
\text { kobiety }\end{array}$ & 2 & 1 \\
\hline 52. & kochanie & $\begin{array}{l}\text { 1. pieszczotliwy zwrot do partnera/ } \\
\text { partnerki } \\
\text { 2. poufały, przymilający zwrot do } \\
\text { kobiety }\end{array}$ & $\begin{array}{l}2 \\
1\end{array}$ & 1 \\
\hline 53. & korek & zator uliczny & 2 & 1 \\
\hline 54. & koszmarny & $\begin{array}{l}\text { 1. zły, trudny, uciążliwy } \\
\text { 2. brzydki, okropny, odrażający }\end{array}$ & $\begin{array}{l}2 \\
1 \\
1\end{array}$ & 2 \\
\hline 55. & lecieć & biec, śpieszyć się, pędzić & 2 & 5 \\
\hline 56. & mieć czas & dysponować wolnym czasem & 2 & 5 \\
\hline 57. & (moja) droga & poufały zwrot do kobiety & 2 & 1 \\
\hline 58. & siedzieć & korzystać z czegoś & 2 & 5 \\
\hline 59. & skoczyć & szybko udać się gdzieś, pośpieszyć & 2 & 5 \\
\hline 60. & straszny & $\begin{array}{l}\text { duży, ogromny } \\
\text { przerażający }\end{array}$ & $\begin{array}{l}2 \\
1 \\
1\end{array}$ & 2 \\
\hline 61. & stuprocentowy & $\begin{array}{l}\text { mający wszystkie cechy typowe dla } \\
\text { określonego rodzaju rzeczy lub osoby }\end{array}$ & 2 & 2 \\
\hline 62. & bałagan & nieporządek, nieład, chaos, rozgardiasz & 1 & 1 \\
\hline 63. & bez dyskusji & bez sprzeciwu & 1 & 8 \\
\hline 64. & beznadziejny & bardzo niedobry, straszny, okropny & 1 & 2 \\
\hline 65. & brać & kupować & 1 & 5 \\
\hline 66. & chodzi (o) & rzecz w tym & 1 & 5 \\
\hline 67. & co & co ty na to? & 1 & 0 \\
\hline 68. & coś ty & $\begin{array}{l}\text { zwrot wyrażający zaskoczenie, } \\
\text { niedowierzanie, sprzeciw }\end{array}$ & 1 & 7 \\
\hline 69. & czarna & kawa naturalna bez mleka & 1 & 2 \\
\hline 70. & dobra & dobrze, zgoda & 1 & 7 \\
\hline 71. & dobry & udany, świetny & 1 & 2 \\
\hline 72. & fakt & rzeczywiście & 1 & 0 \\
\hline 73. & fatalnie & okropnie, źle & 1 & 8 \\
\hline 74. & gadatliwy & lekceważąco o osobie rozmownej & 1 & 2 \\
\hline 75. & hej & $\begin{array}{l}\text { poufała formuła powitalna } \\
\text { lub pożegnalna }\end{array}$ & 1 & 7 \\
\hline
\end{tabular}




\begin{tabular}{|c|c|c|c|c|}
\hline 76. & kac & $\begin{array}{c}\text { stan psychiczno-fizyczny po nadużyciu } \\
\text { alkoholu }\end{array}$ & 1 & 1 \\
\hline 77. & kasa & pieniądze & 1 & 1 \\
\hline 78. & klimat & specyficzny nastrój utworu lub miejsca & 1 & 1 \\
\hline 79. & kropka & koniec, sygnał zamknięcia rozmowy & 1 & 7 \\
\hline 80. & kryminał & powieść kryminalna & 1 & 1 \\
\hline 81. & kurczę & eufemistyczne przekleństwo & 1 & 7 \\
\hline 82. & malutki & bardzo mały & 1 & 2 \\
\hline 83. & mieć & obiecać, zadeklarować się & 1 & 5 \\
\hline 84. & na piechotę & pieszo & 1 & 8 \\
\hline 85. & na razie & forma pożegnania & 1 & 7 \\
\hline 86. & o Boże! & oznaka wzburzenia, zirytowania & 1 & 7 \\
\hline 87. & ochrona & ochroniarz & 1 & 1 \\
\hline 88. & opłacać się & mieć korzyść & 1 & 5 \\
\hline 89. & pa & poufała formuła pożegnania & 1 & 7 \\
\hline 90. & po staremu & $\begin{array}{c}\text { odpowiedź ‘bez zmian’ na pytanie, co } \\
\text { słychać }\end{array}$ & 1 & 8 \\
\hline 91. & pogadać & porozmawiać & 1 & 5 \\
\hline 92. & potwornie & bardzo, ogromnie & 1 & 8 \\
\hline 93. & robota & praca & 1 & 1 \\
\hline 94. & priorytet & list priorytetowy & 1 & 1 \\
\hline 95. & stacjonarny & telefon stacjonarny & 1 & 1 \\
\hline 96. & Stany & Stany Zjednoczone Ameryki Północnej & 1 & 1 \\
\hline 97. & telefon & numer telefonu & 1 & 1 \\
\hline 98. & tu & $\begin{array}{c}\text { (zwrot używany w rozmowie } \\
\text { telefonicznej) }\end{array}$ & 1 & 4 \\
\hline 99. & umówić się & $\begin{array}{c}\text { zaplanować spotkanie z kimś, zwłaszcza } \\
\text { randkę }\end{array}$ & 1 & 5 \\
\hline 100. & walentynki & $\begin{array}{l}\text { święto zakochanych obchodzone } \\
14 \text { lutego }\end{array}$ & 1 & 1 \\
\hline 101. & wpaść & $\begin{array}{c}\text { przyjść, przyjechać gdzieś, do kogoś na } \\
\text { krótko, zajść, odwiedzić }\end{array}$ & 1 & 5 \\
\hline 102. & wściekły & bardzo zły, rozgniewany & 1 & 2 \\
\hline 103. & z hakiem & $\mathrm{z}$ dodatkiem, $\mathrm{z}$ okładem & 1 & 8 \\
\hline
\end{tabular}

a Oznaczenia części mowy następującymi cyframi: 0 - partykuła, 1 - rzeczownik, 2 - przymiotnik i imiesłów przymiotnikowy, 3 - liczebnik główny, porządkowy i pozostałe rodzaje mające formę przysłówkową, 4 - zaimek rzeczowny, przymiotny i przysłowny, 5 - czasownik, 6 - przyimek, 7 - wykrzyknik pierwotny i wtórny, 8 - przysłówek, 9 - spójnik, przyjmuję za pracą M. Za- 
rębiny Próba statystycznej analizy słownictwa polszczyzny mówionej (synteza danych liczbowych), Wrocław-Warszawa-Kraków, 1985, s. 31.

${ }^{\mathrm{b}}$ Podobnie jak M. Zarębina, zsubstantywizowane nazwy języków polski, hiszpański traktuję jako rzeczowniki, podobnie jak wyrazy: kochana, (moja) droga, 'poufałe zwroty do kobiety', stacjonarny 'telefon stacjonarny' (Zarębina 1985, s. 35).

' Leksemy biała 'kawa z mlekiem' i czarna 'kawa bez mleka', ze względu na obecność i konieczność użycia w wypowiedziach rzeczownika kawa, traktuję jako przymiotniki. Komunikat Poproszę biała jest niepełny, gdyż na przykład stanowić może jedynie replikę na pytanie Jaka chce Pan/Pani kawę lub elipsę komunikatu [Poproszę] biała [kawę].

${ }^{\mathrm{d}}$ Wyraz zero traktuję jako rzeczownik ze względu na odmianę rzeczownikową.

Opracowanie własne

Konrad Kazimierz Szamryk

\section{COLLOQUIAL LEXIS IN POLSKI, KROK PO KROKU, A HANDBOOK FOR LEARNING POLISH AS A FOREIGN LANGUAGE (A1 LEVEL) - SELECTED ISSUES FROM STATISTICAL PERSPECTIVE}

Keywords: colloquial lexis, Polish as a foreign language, glottodidactics, Polish language handbooks for foreigners, statistics

Summary. This article focuses on colloquial lexis in a handbook for learning Polish as a foreign language Polski, krok po kroku (A1 level) in statistic perspective. The researcher quoted 103 colloquial entries from the above mentioned book, which had been used 541 times. Based on investigations, an average frequency rate for colloquial lexis was calculated and vocabulary was distinguished from the perspective of its occurrence, i.e. used very often, often, rarely and very rarely. This paper also presents colloquial lexis blind statistical rates and their division into parts of speech. On the basis of conducted research, the author makes a conclusion that only a fifth part of quoted colloquial vocabulary may be remembered by students at Polish language classes. Thus the large amount of analyzed lexis does not form a subject of intentional and conscious teaching, and mainly serves creating an impression of an oral discourse. 